Distribution 1

\title{
OIL RECOVERY IMPROVEMENT THROUGH PROFILE MODIFICATION BY THERMAL PRECIPITATION
}

\author{
Quarterly Report for the Perigh \\ April-June 1991 \\ By \\ John Reis

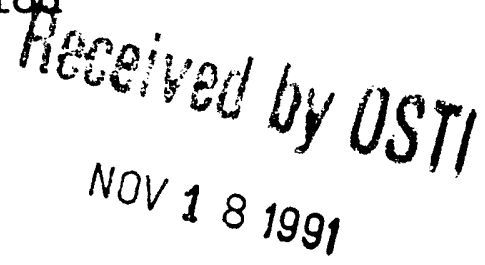

Work Performed Under Contract No. AC22-90BC14660

\author{
Gene Pauling, Project Manager \\ Metairie Site office \\ 900 Commerce Road \\ New Orleans, LA 70123
}

\author{
Prepared by \\ University of Texas \\ Austin, $T X$
}

\section{DISCLAIMER}

\begin{abstract}
This report was prepared as an account of work sponsored by an agency of the United States Government. Neither the United States Government nor any agency thereof, nor any of their employees, makes any warranty, express or implied, or assumes any legal liability or responsibility for the accuracy, completeness, or usefulness of any information, apparatus, product, o: process disclosed, or represents that its use would not infringe privately owned rights. Reference herein to any specific commercial product, process, or service by trade name, trademark, manufacturer, or otherwise doss not necessarily constitute or imnly its endorsement, recommendation, or favoring by the United States Government or any agency thereof. The views and opinions of authors expressed herein do not necessarily state or reflect those of the United States Government or any agency thereof.
\end{abstract}




\section{OIL RECOVERY IMPROVEMENT THROUGH PROFILE MODIFICATION EY THERMAL PRECIPITATION}

\section{OBJECTIVE}

The objective of this study is to develop the method of temperature dependent precipitation as a means to modify injection profiles in petroleum reservoirs. A saturated solution is injected into a reservoir at high temperature and allowed to cool. If the chemical has a decreasing solubility with decreasing temperature, the chemical will precipitate in the reservoir. This will plug that part of the reservoir and divert subsequently injected fluids into other regions of the reservoir.

\section{SUMMARY OF TECHNICAL PROGRESS}

During this reporting period, construction of the experimental apparatus was nearly completed. The survey of candidate chemicals was expanded. The solubility data for the expanded list of chemicals has been obtained, the solution density data are being assembled, and the Material Safety Data Sheets (MSDSs) are being collected. The development of the simple models for the porosity reduction during thermal precipitation has been completed.

During the next quarter, the core holder will be completed and incorporated into the experimental apparatus. Initial measurements of sample porosity and permeability will begin.

\section{Porosity Reduction from Cooling by Convection}

If a hot solution is injected into a cool formation, the following analysis can be used to provide an estimate for how much the porosity would be recluced. As an example, a brine solution of sodium chloride is considered.

The enthalpy, $Q$, required to raise the temperature of a bulk volume of reservoir, $V_{R}$, initially at temperature, $T_{2}$, to a final reservoir temperature, $T_{1}$, by injecting hot saturated solution at temperature, $T_{1}$, is given by:

$$
Q=V_{R} * M_{R}^{*}\left(T_{1}-T_{2}\right) \text {, }
$$

where $M_{R}$ is the volumetric heat capacity of the reservoir.

The temperature of the chemical saturated solution starts dropping as it passes through the cooler reservoir. The drop in temperature alters the chemical solubility, which results in precipitation of the chemical. Assuming the chemical saturated solution ultimately cools to a final temperature, $T_{2}$, the volume of chemical solution required to heat the reservoir rock from $T_{2}$ to $T_{1}$ can be computed through a heat balance:

$$
\mathrm{Q}=\mathrm{V}_{\mathrm{t}} * \mathrm{M} *\left(\mathrm{~T}_{1}-\mathrm{T}_{2}\right)+\mathrm{V}_{\text {precipitate }} * \frac{\rho_{\text {precipitate }}}{\mathrm{M}_{\mathrm{w}}} * \Delta H
$$

where $V_{t}$ is the volume of chemical saturated hot solution injected at an initial temperature, $T_{1}, M$ is the volumetric heat capacity of the saturated solution, $V_{\text {precipitate }}$ is the volume of 
precipitate, $\rho_{\text {procipitate }}$ is the density of the precipitate, $M_{w}$ is the molecular weight of the precipitate, and $\Delta \mathrm{H}$ is the heat of solution of the precipitate.

It can be shown that the heat of solution is negligible compared to the enthalpy required to heat the formation through an energy balance. Assume a saturated solution of sodium chloride at $500^{\circ} \mathrm{F}$ is injected through one cubic foot formation, initially at $100^{\circ} \mathrm{F}$. The volumetric heat capacity of the reservoir, $M_{R}$, over the temperature range of $500^{\circ} \mathrm{F}$ to $100^{\circ} \mathrm{F}$ is taken to be $32 \mathrm{BTU} / \mathrm{ft}^{3}$. Substituting these values in Eq. 1, we find that enthalpy needed to heat the cubic foot of formation is 12,800 BTU.

The maximum enthalpy release from the heat of solution during precipitation will occur if the porosity is reduced to zero. In this case, the volume of precipitate would be $\phi *$ $\mathrm{V}_{\mathrm{R}}$. For a heat of solution for sodium chloride of $1.164 \mathrm{BTU} / \mathrm{b}$-mole, a molecular weight of $58.5 \mathrm{lbm} / \mathrm{lb}$-mole, a precipitate density of $134.74 \mathrm{lb} / \mathrm{ft}^{3}$, and a reservoir porosity of $16 \%$, the maximum enthalpy released during precipitation within one cubic foot of reservoir would be 0.43 BTU. Since this value is very small with respect to the 12,800 BTU needed to heat the formation, the heat of solution can be neglected in the energy balance. we obtain:

If the second term of Eq. 2 is neglected and the equation is combined with Eq. 1,

$$
v_{t}=\frac{V_{R}^{*} M_{R}}{M}
$$

This equation gives the volume of hot solution required to heat the given volume of reservoir to the temperature of the injected solution. The volume of precipitate, $V_{\text {precipitate }}$ at lower temperature, $T_{2}$, has been previously reported as

$$
\frac{V_{\text {precipitate }}}{V_{t}}=\left(\frac{M_{1}-M_{2}}{\rho_{\text {precipitate }}}\right) *\left(\frac{\rho_{1}}{M_{t}}\right)
$$

where $M_{1}$ and $M_{2}$ are the masses of chemical dissolved in the solution at the high and low temperatures, respectively, and $M_{t}$ is the total mass of the solution at $T_{1}$.

Substituting the value of $\mathrm{V}_{\mathrm{t}}$ from Eq. 3 into Eq. 4 we obtain:

$$
\mathrm{V}_{\text {precipitate }}=\left(\frac{\mathrm{M}_{1}-\mathrm{M}_{2}}{\rho_{\text {precipitate }}}\right) *\left(\frac{\rho_{1}}{M_{\mathrm{t}}}\right) * \frac{\mathrm{V}_{\mathrm{R}} * \mathrm{M}_{\mathrm{R}}}{\mathrm{M}}
$$

If the hot solution displaces all of the other fluids in the reservoir, the bulk volume of the reservoir occupied by the solution can be expressed in terms of porosity and the volume of chemical saturated hot solution injected:

$$
v_{R}=\frac{v_{t}}{\phi}
$$

Combining Eqs. 5 and 6 we obtain the following expression for the ratio of the volume of the precipitate to that of the initial solution for the thermal precipitation by convection process: 


$$
\frac{V_{\text {precipitale }}}{V_{t}}=\left(\frac{M_{1}-M_{2}}{\rho_{\text {precipitate }}}\right) *\left(\frac{\rho_{1}}{M_{t}}\right) * \frac{M_{R}}{M * \phi} .
$$

This ratio is also equal to the fractional reduction in porosity:

$$
\frac{\Delta \phi}{\phi}=\frac{V_{\text {precipitate }}}{V_{t}}
$$

The reduction in porosity for thermal precipitation by convection using sodium chloride is calculated in the following example. The volumetric heat capacity, $M_{R}$, is 32 $\mathrm{BTU} / \mathrm{ft}^{3}$. The volumetric heat capacity of a sodium chloride solution $(\mathrm{M})$ over the temperature range of $500^{\circ} \mathrm{F}$ to $100^{\circ} \mathrm{F}$ is $55 \mathrm{BTU} / \mathrm{ft}^{3}{ }^{\circ} \mathrm{F}$. The mass of sodium chloride dissolved in the solution, $M_{1}$ and $M_{2}$, is obtained from its solubility at the high and low temperatures, respectively. For a rock porosity of $16 \%$, Eq. 8 yields a fractional reduction in porosity of $26.8 \%$. This is about three times higher than the porosity reduction for the conductive cooling process reported in the previous quarterly report.

\section{PUBLICATIONS}

There were no publications during this reporting period. 

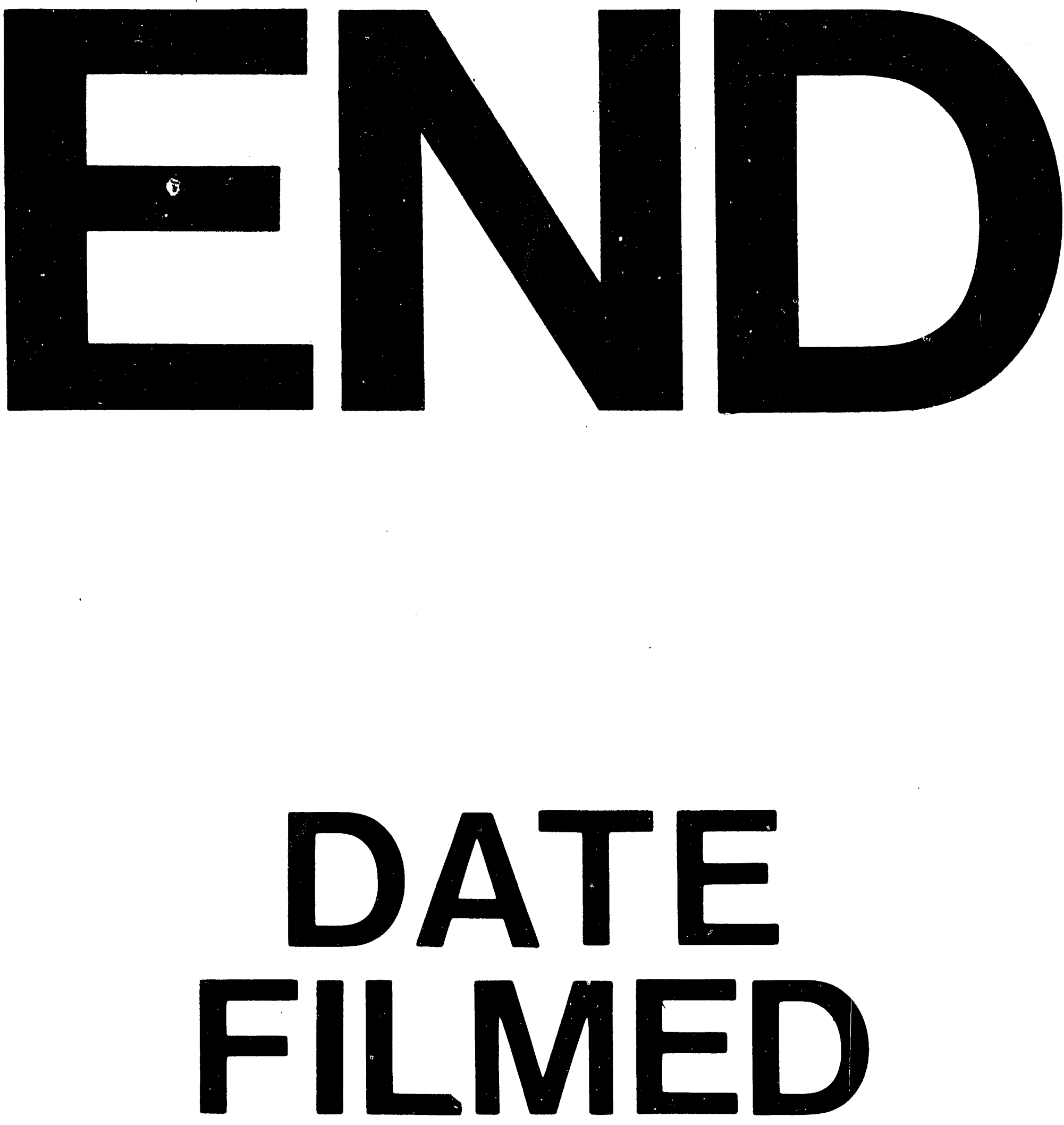

$A$

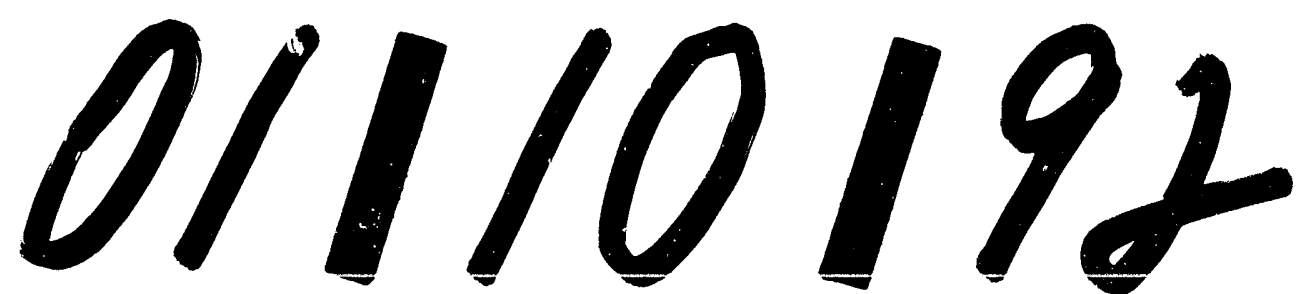


